\title{
PROLAPSUS UTERI PASCA MELAHIRKAN PADA KUCING MIX
}

\author{
Ratna Widyawati ${ }^{1}$, Desty Apritya ${ }^{1^{*}}$ \\ Fakultas Kedokteran Hewan, Universitas Wijaya Kusuma Surabaya \\ *Email : destyapritya@uwks.ac.id
}

\begin{abstract}
2-year-old female cat with a history of giving birth. Physical examination showed that the uterine mucosa has protusio or eversion through the vagina and vulva and hangs out. The protruding uterus was amputated and ovariohysterectomy was performed. Laparotomy was performed to ligated the ovarian artery, uterine artery, ovarian removal and vaginopexy. Antibiotic, analgesic and immunostimulants was given postoperative. The incision of the wound was closed for approximately 1 week.
\end{abstract}

Keywords: uterine Prolaps, amputasi, ovariohisterectomy

\section{PENDAHULUAN}

Prolapsus Uteri adalah eversi atau protusio bagian mukosa uterus keluar melalui cervix atau vagina (Fossum, 2006). Penyebab prolapsus uteri adalah distokia, sehingga mengakibatkan munculnya tenesmus berlebihan, pengeluaran plasenta yang tidak tuntas, kurangnya exercise sebelum melahirkan dan waktu melahirkan yang lama (D'Oliveira et al, 2009). Selain itu menurut Zeynep, et al (2018) menyebutkan faktor predisposisi penyebab prolapsus uteri adalah karena kontraksi yang berlebihan akibat induksi oksitosin saat melahirkan, dilatasi cevix uterus yang berlebihan, relaksasi dan stretcing muskulus sekitar pelvis, serta pemisahan membran plasenta yang tidak komplit. Prolapsus uteri dapat terjadi pada kucing mulai umur 10 bulan hingga enam tahun (Ozyurtlu and Kaya, 2005) . Ekstrand and Lendeforsberg (1994) melaporkan terdapat $0,6 \%$ kejadian pada induk kucing yang mengalami distokia dari 155 kasus.

\section{KASUS}

\section{Sinyalemen, anamnesa dan gejala klinis}

Seekor kucing betina berusia sekitar 2 tahun setelah ke 5 anaknya lahir, mukosa uterus keluar hingga melewati vulva dan menggantung keluar selama 48 jam. Uterus berbau menyengat, dan berwarna merah kehitaman (gambar 1).

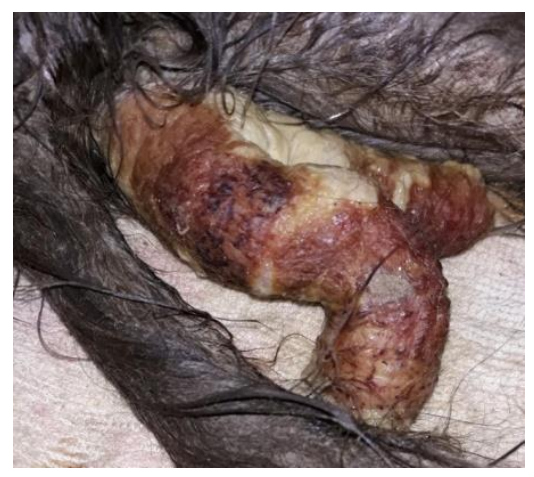

Gambar 1. Prolapsus uteri dengan keluarnya kedua cornua uteri

Pemeriksaan fisik, diagnosa, diagnosa pembanding dan prognosa

Pemeriksaan fisik pada kasus ini yaitu mukosa uterus menonjol keluar dari vulva, membesar dan mengeras bila dipalpasi. Uterus berwarna kekuningan dan beberapa bagian berwarna merah gelap dengan bau busuk yang menyengat. Mukosa sudah tidak berwarna merah segar, walau sudah dibersihkan. Kucing mengalami hipotermi dengan suhu mencapai $37,7^{\circ} \mathrm{C}$. Diagnosa pada kasus ini adalah Prolapsus uteri. Diagnosa pembandingnya antara lain 
prolapsus rektum, tumor. Prognosa pada kasus ini adalah Fausta.

\section{Terapi dan Penanganan}

Pemotongan dilakukan pada corpus uteri yang dekat dengan vulva. Dilakukan pengompresan menggunakan es batu untuk mengecilkan ukuran corpus uteri yang mengalami oedematous. Laparotomy dilakukan untuk mengangkat ovarium. Untuk mencegah corpus uteri keluar lagi, maka dilakukan penempelan vagina pada dinding abdomen. Post operasi diberikan terapi antibiotik, analgesik dan imunostimulan yang diberikan selama 5 hari.

\section{DISKUSI}

Prolapsus uteri umumnya terjadi pada hewan post partus. Perejanan yang kuat saat melahirkan mengakibatkan uterus menyembul keluar. Cervix mengalami dilatasi sehingga uterus dapat keluar melewatinya. Salah satu atau kedua cornua uteri dapat keluar, berada di dalam vagina atau mengalami eversi melewati vulva (Deroy, et al 2015). Prolapsus uteri diikuti dengan kemerahan pada mukosanya. Jaringan yang mengalami eversi membentuk seperti "bentukan donat" dan mengalami perubahan warna akibat kongesti vena, trauma dan kontaminasi kotoran (Fossum, 2006). Prolapsus uteri dapat mengakibatkan ligamentum lata uteri putus. Penanganan yang pertama adalah membersihkan uterus yang menonjol keluar dengan larutan dextrose hipertonik untuk mengurangi kebengkaan dan dikompres dengan icepack. Kemudian dilakukan flushing menggunakan cairan steril. Karena pada kasus ini telah terjadi nekrosis pada mukosa uterus, mengingat pemilik hewan baru membawa kucing tersebut setelah mengalami prolapsus selama 48 jam maka uterus harus dilakukan amputasi dan ovariohisterektomi $(\mathrm{OH}) . \mathrm{OH}$ dapat dilakukan apabila jaringan mengalami necrosis, devitalized, irreducible, atau apabila pembuluh darah pada ligamentum mengalami ruptur (Bruinsma, 1981)

Terapi cairan yang digunakan adalah Ringer Lactat pada vena cephalica. Premedikasi yang diberikan adalah acepromacin $0,05 \mathrm{ml} / \mathrm{kg} \mathrm{BB}$ dan atropin $0,04 \mathrm{mg} / \mathrm{kg} \mathrm{BB}$. Anastesi yang digunakan adalah ketamin ${ }^{\circledR} 20 \mathrm{mg} / \mathrm{kg}$ BB. Pasien ditidurkan dengan posisi rebah dorsal.

Sebelum dilakukan amputasi, uterus yang keluar dijahit pada sekeliling corpus uteri yang akan dipotong, kemudian klem uterus dengan rochester carmalt, lalu potong bagian caudal dari klem. Setelah itu jahit dengan pola parker ker untuk menutup lumen uterus. Laparotomi dilakukan dengan menginsisi linea alba pada caudal umbilicus. Traksi dari uterus menyebabkan arteri ovarica berada pada lokasi yang abnormal, yaitu terletak di dorsocaudal abdomen. Arteri tidak mengalami ruptur, nampak menegang dan memanjang. Arteri ovarica diligasi kemudian dipotong, begitu pula dengan arteri uterina. Untuk mencegah keluarnya kembali uterus, maka dilakukan penempelan vagina pada dinding abdomen (vaginapexy) (Fossum,2006). Terapi yang diberikan pasca operasi adalah pemberian antibiotik, analgesik dan peningkat sistem imun. Pada luka insisi diberikan de die yo jing (obat merah cina). Dalam waktu 7 hari luka sudah mengering dan menyatu. Serta kucing sudah dapat beraktivitas normal, makan dan minum teratur.

\section{KESIMPULAN}

Prolapsus uteri dapat didiagnosa dengan pemeriksaan secara visual dan apabila mukosa uterus mengalami nekrosis maka penanganannya adalah amputasi uterus dan ovariohisterektomy. Untuk menghindari prolapsus vagina maka dilakukan vaginapexy. 


\section{REFERENSI}

Bruinsma,D.L. 1981. Feline Uterine Prolaps (a Case Report). Vet Med Small Anim Clin;76:60.

D’Oliveira,K.S. Veiga, G.A.L, Barbosa,A. Brito,C. Kitahara, F. Bernardes,J.P. Carramenha, C.P. 2009. Bicornual Uterine Prolapse in Cat. World Small Animal Veterinary Association World Congress Proceedings. Brazil. https://www.vin.com/apputil/content/de faultadv1.aspx?id=4253072\&pid=1129 0\&print $=1$

Deroy,C. Bismuth,C. Carozzo,C. 2015. Management of a Complete Uterine Prolapse in a Cat. Journal of Feline
Medicine and Surgery Open Reports. Jan-Jun;1(1):2055116915579681. Diakses tanggal7/7/2019; https://www.ncbi.nlm.nih.gov/pmc/artic les/PMC5362873/

Ekstrand C, Linde-Forsberg C.1994. Dystocia in the cat: a retrospective study of 155 cases. J Small Anim Pract 1994; 35: 459-464

Fossum T.W.2006.Small Animal Surgery.2nd ed.Mosby ST, London

Ozyurtlu N, Kaya D, .2015. Unilateral Prolapse in a Cat. Turk J Vet Anim Sci 2005;29:941-943.

Zeynep, GUNAY UCMAK, Melih UCMAK, Ali Can CETIN, Cagatay TEK.2018. Uterine Prolapse in Pregnant Cat. Turk Vet Anim Sci 42:500-502. 